\title{
End of an Epic? The Draft Agreement on the EU's Accession to the ECHR
}

\author{
Tobias Lock*
}

This contribution aims to analyse and assess the draft agreement on the European Union's (EU) accession to the European Convention on Human Rights (ECHR). ${ }^{1}$ The draft agreement was drawn up by a so-called 'informal working group' situated within the Council of Europe's Steering Committee on Human Rights (CDDH). The group consisted of fourteen experts, seven from EU Member States and seven from non-EU countries, who had been chosen on the basis of their experience and not as representatives of their governments. The meetings were held with representatives of the European Commission, which had been issued with a negotiating mandate by the Council of the $\mathrm{EU},{ }^{2}$ and were attended by experts from the Council of Europe. ${ }^{3}$ Negotiations started in July 2010 and a draft agreement was presented on 24 June 2011, which was endorsed by the CDDH on 14 October 2011. Currently, negotiations are ongoing within the European Union, with notably the United Kingdom and France advocating amendments to the draft agreement, which will be referred to where relevant to this contribution. ${ }^{4}$ However, the core features of the draft agreement, which are the subject of this article, do not seem to be in doubt.

Over thirty years after the European Commission first mooted an accession by the EU to the ECHR and almost twenty years after the ECJ rendered Opinion 2/94, which clarified that accession would be impossible without an explicit competence in the Treaties, this draft agreement might mean the end to a discussion of almost epic proportions. ${ }^{5}$ But even if the draft agreement is

* Dr Tobias Lock, Lecturer, School of Law, University of Surrey, Guildford GU2 7XH, E-mail: t.lock@surrey.ac.uk; I would like to thank Professor Piet Eeckhout for helpful comments. All errors remain, of course, my own.

${ }^{1} \mathrm{CDDH}(2011) 009$.

${ }^{2}$ Council Resolution authorising the Commission to negotiate the Accession Agreement of the European Union to the European Convention for the protection of Human Rights and Fundamental Freedoms (ECHR), doc no 9689/10 (11 May 2010), which is partly classified.

${ }_{3} \mathrm{CDDH}$, ad hoc terms of reference, CDDH(2010)008.

${ }^{4}$ Should the EU agree to propose changes, these would then have to be negotiated with the Council of Europe, of Council of the EU, doc no 18117/11, para 8.

5 Pre-Lisbon publications include: H Golsong, 'Grundrechtsschutz im Rahmen der Europäischen Gemeinschaften' [1978] Europäische Grundrechtezeitschrift 346; European Commission, 
endorsed by the European Union and the Council of Europe, its ratification may take some time. ${ }^{6}$ The EU's internal ratification process requires unanimity in the Council, the consent of the European Parliament, and separate approval by the Member States according to their constitutional traditions. ${ }^{7}$ Moreover, the draft accession agreement does not provide rules on how ECHR membership is dealt with by the EU internally. Internal rules, eg on the details of the prior involvement of the ECJ, will also have to be drawn up and agreed upon by all EU Member States. ${ }^{8}$ In addition, all parties to the ECHR must ratify the agreement. Given the lengthy ratification process for Protocol No 14, accession may not happen as swiftly as some may hope for. ${ }^{9}$

As a background to the following discussion, it is necessary to briefly address the situation pre-accession. While the EU cannot be held directly responsible before it, ${ }^{10}$ the Strasbourg Court has developed a sophisticated set of case-law on the indirect responsibility of the EU, which is accomplished by holding its Member States responsible instead. One can distinguish three scenarios, which are of relevance to this paper. According to the Matthews decision, the EU's Member States are responsible for violations of the Convention found in the EU's primary law, ie mainly the Treaties. ${ }^{11}$ The reasoning in Matthews was

'Memorandum on the accession of the Communities to the European Convention for the Protection of Human Rights and Fundamental Freedoms' Bull EC Supp 2/79; M Ruffert, 'Anmerkung zu Gutachten 2/94' [1996] Juristenzeitung 624; S Winkler, Der Beitritt der Europäischen Gemeinschaften zur Europäischen Menschenrechtskonvention, (Nomos: Baden-Baden, 2000); B Moriarty, EC Accession to the ECHR' [2001] Hibernian Law Journal 13; K Strasser, Grundrechtsschutz in Europa und der Beitritt der Europäischen Gemeinschaften zur Europäischen Menschenrechtskonvention (Peter Lang: Frankfurt, 2001); W Schaller, 'Das Verhältnis von EMRK und deutscher Rechtsordnung vor und nach dem Beitritt der EU zur EMRK' [2006] Europarecht 656; more recent publications include: V Skouris, 'First Thoughts on the Forthcoming Accession of the European Union to the European Convention of Human Rights' in D Spielmann, M Tsirli, and P Voyatzis (eds), The European Convention on Human Rights, a Living Instrument (Bruylant: Brussels, 2011), 555; N O’Meara, ‘A More Secure Europe of Rights? The European Court of Human Rights, the Court of Justice of the European Union and EU Accession to the ECHR' (2011) 12 German Law Journal 1813; P Gragl, 'Der rechtliche Status der EMRK innerhalb des Unionsrechts. Zu den Auswirkungen auf die Rechtsautonomie der Europäischen Union nach ihrem Beitritt zur EMRK' (2011) 14 Zeitschrift für Europarechtliche Studien 409; JP Jacqué, 'The Accession of the European Union to the European Convention on Human Rights and Fundamental Freedoms' (2011) 48 CMLRev 995.

6 In addition, a new Opinion by the ECJ is likely.

7 Article 218(6) and (8) TFEU; it is important to note that the United Kingdom's approval to the accession Treaty will not be subjected to a so-called 'referendum lock' under the European Union Bill. Section 10 of the Bill makes it clear that the government may give its approval to the accession agreement under Art 218(8) TFEU once the agreement has passed through Parliament.

${ }_{8}$ A classified set of draft rules have been prepared for adoption by the Council, Council of the EU doc no $10744 / 12$.

9 On the other hand, Kuijer has suggested that Russia, which had long blocked Protocol No 14, would be pleased to see that the EU is finally joining the Convention, cf M Kuijer, 'The Accession of the European Union to the ECHR' Amsterdam Law Forum, Vol 3, No $4<$ http://www.amsterdam lawforum.org> accessed 13 December 2011.

${ }_{10}$ Confédération française du travail v European Communities, no 8030/77, 13 DR 236.

11 Matthews $v$ United Kingdom [GC], no 24833/94, ECHR 1999-I. 
based on the notion that while the Convention allowed the Member States to transfer sovereign power onto an international organization, violations of the Convention by that organization would be attributable to them. The Member States were thus deemed unable to escape their obligations under the Convention. This reasoning was employed again in the Bosphorus case where the compatibility of secondary EU law (a Council Regulation) was at issue. ${ }^{12}$ In Bosphorus, the Court distinguished between acts of secondary law which give discretion to Member States in their implementation and those which do not. For the latter, the Court introduced a presumption that acts are compatible with the Convention unless there was a 'manifest deficit' in the protection of Convention rights in the concrete case. In all other cases, the Member States are fully responsible. ${ }^{13}$ The final scenario of relevance here is a situation where there is no Member State involvement but only action by the EU. In the case of Connolly, it became evident that in such cases there is a gap in the protection by the Strasbourg Court. ${ }^{14}$ The Court considered that the alleged infringement was not attributable to the respondent Member State since it did not happen within its jurisdiction as is required by Article 1 ECHR. The EU's accession to the ECHR will close this gap in the external supervision by the ECtHR since after accession the EU will be directly responsible in such cases.

The following pages first discuss the effects which accession will have on the system of human rights protection under the ECHR focusing on the most relevant features of the accession agreement, such as the co-respondent mechanism and the prior involvement of the ECJ. The second part of this contribution explores the future status of the ECHR in the EU's legal order.

\section{The EU as a Party to the ECHR: Changes to the ECHR System}

The accession agreement focuses exclusively on the ECHR system of human rights protection and does not directly deal with European Union law. ${ }^{15}$ The agreement foresees some amendments to the ECHR itself, but the details of the EU's involvement in the ECHR will be regulated by the accession agreement to which the (amended) ECHR will make explicit reference. ${ }^{16}$ The most important changes concern the procedure before the European Court of Human Rights (ECtHR) in cases involving the EU. The rules of the accession agreement are drafted in a very general and open-ended manner. It seems that this was done deliberately in light of the difficulties faced by the negotiators. They had to

\footnotetext{
12 Bosphorus v Ireland [GC], no 45036/98, ECHR 2005-VI.

13 See for instance M.S.S. v Belgium and Greece [GC], no 30696/09, 21 January 2011.

${ }_{14}$ Connolly $v 15$ Member States of the European Union, no 73274/01, 9 December 2008.

15 Otherwise the agreement might violate the autonomy of EU law, cf T Lock, 'Walking on a Tightrope' (2011) 48 CMLRev 1025, 1028 et seq.

16 cf Art 1(2) accession agreement, amending Art 59(2) ECHR, CDDH-UE(2011)16.
} 
strike a balance between their aim of accomplishing accession and the constraints of European Union law, and in particular the ECJ's strict case-law on the conferral of jurisdiction on international courts, a stance which it recently reaffirmed in Opinion 1/09 on the European Patents Court. ${ }^{17}$ The negotiators therefore opted for relatively general rules in the draft accession agreement which would be supplemented by rules internal to the European Union. At the time of writing the latter have not yet been publicized. ${ }^{18}$

\section{A. The Co-respondent Mechanism}

The European Union will be an unusual party to the ECHR. The reason is that where EU law is at stake, there is often a separation between the law-making entity (the EU) and the executing entity (the Member State). While this is not unusual in a federal setting, with which the EU can be compared, it is unheard of that both federation (EU) and constituent States (Member States) are parties to the ECHR. Since most EU legislation is implemented by the Member States and since the EU only rarely acts vis-à-vis individuals, an applicant would usually find it difficult to ascertain who was responsible for the infringement of his human rights: the EU or the Member State, the authorities of which were in contact with the individual. In such a situation, an applicant has the option to hold one of them alone responsible or both together. In either scenario a further complication arises in that a respondent might raise the defence that it was not responsible for the violation, eg because it (a Member State) only followed its strict obligations under EU law. ${ }^{19}$ If this were possible, the ECtHR would be forced to engage in an interpretation of the EU Treaties and possibly of the division of competence between the EU and the Member States, which would be incompatible with the autonomy of the EU's legal order. That autonomy requires that the procedures for resolving disputes will not have the effect of binding the $\mathrm{EU}$ and its institutions to a particular interpretation of the rules of EU law. ${ }^{20}$ The EU would therefore be unable to agree to such a model. ${ }^{21}$ This is why Article 1 of Protocol No 8 to the Lisbon Treaty stipulates that the accession agreement must make provision for preserving the specific characteristics of the Union and Union law, especially by ensuring that individual applications are correctly addressed to the EU and/or the Member States as appropriate. ${ }^{22}$

\footnotetext{
17 Opinion 1/09 European and Community Patents Court [2011] ECR I-00000.

18 A classified draft exists, however, cf Council Document 10744/12.

19 Such situations have been explicitly recognized by the ECtHR in the Bosphorus presumption, which in practice has the same effect as a defence.

20 Opinion 1/00 [2002] ECR I-3493, para 13.

21 cf Lock, n 15.

22 Protocol No 8 to the Lisbon Treaty [2010] OJ C 83/273.
} 
For this reason the drafters developed the so-called co-respondent mechanism. ${ }^{23}$ Further considerations guiding its adoption were to ensure the accountability for violations of the ECHR, the enforceability of judgments against the party which is capable of removing the violation, and to allow that party to fully participate in the proceedings before the ECtHR. ${ }^{24}$ Thus the mechanism is deemed to serve the proper administration of justice. The draft agreement provides that Article 36 ECHR should be amended as follows:

The European Union or a member State of the European Union may become a co-respondent to proceedings by decision of the Court in the circumstances set out in the Agreement on the Accession of the European Union to the European Convention for the Protection of Human Rights and Fundamental Freedoms. A co-respondent is a party to the case. The admissibility of an application shall be assessed without regard to the participation of a co-respondent in the proceedings.

The accession agreement itself contains further details in Article 3:25

2. Where an application is directed against one or more member States of the European Union, the European Union may become a co-respondent to the proceedings in respect of an alleged violation notified by the Court if it appears that such allegation calls into question the compatibility with the Convention rights at issue of a provision of European Union law, notably where that violation could have been avoided only by disregarding an obligation under European Union law.

3. Where an application is directed against the European Union, the European Union member States may become co-respondents to the proceedings in respect of an alleged violation notified by the Court if it appears that such allegation calls into question the compatibility with the Convention rights at issue of a provision of the Treaty on European Union, the Treaty on the Functioning of the European Union or any other provision having the same legal value pursuant to those instruments, notably where that violation could have been avoided only by disregarding an obligation under those instruments.

4. Where an application is directed against and notified to both the European Union and one or more of its member States the status of any respondent may be changed to that of a co-respondent, if the conditions in paragraph 2 or paragraph 3 are met.

\footnotetext{
${ }^{23}$ It is based on a proposal contained in a 2002 study by the $\mathrm{CDDH}$ on the technical and legal issues of a possible EC/EU accession to the European Convention on Human Rights, $\mathrm{CDDH}(2002) 010$ Addendum 2.

${ }^{24}$ CDDH-UE(2011)16, para 33.

25 The United Kingdom proposed to return to an earlier, narrower draft of the co-respondent mechanism, which was not supported by other delegations in the Council of Ministers, cf Council of the EU, doc no $16385 / 11$.
} 
5. A High Contracting Party shall become a co-respondent only at its own request and by decision of the Court. The Court shall seek the views of all parties to the proceedings. When deciding on such request the Court shall assess whether, in the light of the reasons given by the High Contracting Party concerned, it is plausible that the conditions in paragraph 2 or paragraph 3 are met.

\section{(i) General Remarks on the Involvement of the Co-respondent}

In line with its rationale explored above, the co-respondent mechanism will be limited to the EU context. ${ }^{26}$ In order to appreciate the unique position of the co-respondent it is necessary to point out the differences to a third-party intervention and to multiple respondents. In contrast to a third party intervening in proceedings under Article 36 (1) and (2) ECHR, the co-respondent becomes a party to the proceedings and is consequently bound by the Court's judgment. ${ }^{27}$ In a similar vein, both respondent and co-respondent must agree to a friendly settlement or to make unilateral declarations. In that sense the leeway for both respondent and co-respondent is restricted.

A party can also become co-respondent where a case was directed against both the EU and one or more Member States as multiple respondents from the outset. This provision deserves explanation since it is not obvious why it is needed. Where a case is directed against multiple respondents, the case is treated like a bundle of applications each of which is directed against one respondent. They are merely joined together. As a consequence, each application needs to fulfil the admissibility criteria laid down in Articles 34 and 35 ECHR, the most important of which is the requirement to exhaust domestic remedies. In contrast, where one of the parties is co-respondent, there is no need for the applicant to exhaust the remedies in the co-respondent's legal order since the admissibility of a case is assessed without regard to the participation of a co-respondent.

The decision whether a party will be allowed to join proceedings as co-respondent, ie whether its status will be changed to that effect, lies with the ECtHR on the request of the party. The Court has no discretion in the matter. Most notably, it cannot force the EU or a Member State to become co-respondent as the status of co-respondent is voluntary. ${ }^{28}$ The explanatory report suggests that the question of co-respondent will only become relevant

\footnotetext{
26 Where other non-Member States apply EU law because of separate agreements (eg the Schengen agreement), the EU can only be involved via the third-party intervention, cf CDDH-UE(2011)16, para 40.

27 The explanatory report makes it clear that there is still room for the EU to intervene in proceedings where the co-respondent mechanism is not applicable, CDDH-UE(2011)16, paras 39-40.

${ }^{28}$ An appraisal of the voluntary character of the mechanism can be found below.
} 
where an individual application was communicated to the respondent. ${ }^{29}$ Communication only happens where an application is not clearly inadmissible, ${ }^{30}$ which would include many manifestly ill-founded applications. Thus the question of whether a co-respondent should be joined will only be relevant in few cases. Furthermore, the admissibility of the application will be assessed without regard to the participation of the co-respondent, ie as if the case were only brought against the respondent. Thus the earliest a party may make a request to become co-respondent is after the case has been communicated to the original respondent. But the draft agreement does not address the question of the latest possibility for the co-respondent to join proceedings. Since one of the purposes of the co-respondent mechanism is to allow full participation of the co-respondent in proceedings, it would seem appropriate that there should be a time limit for the co-respondent to join. It is common for the Court to give the parties a final opportunity to make submissions. Since all submissions after that are considered as unsolicited and will not normally be admitted to the file, ${ }^{31}$ a co-respondent should not be allowed to make submissions after this point in time. It follows that at this stage it should no longer be allowed to join either.

A related question would be whether in case of a referral to the Grand Chamber under Article 43 ECHR a potential co-respondent would be able to join proceedings after the referral has taken place. The Grand Chamber is not limited in its examination of the case to grounds of appeal or to the submissions of the party requesting the referral. Rather it 'may employ the full range of judicial powers conferred on the Court'. ${ }^{32}$ Since the Grand Chamber allows new pleadings, there is no argument why a co-respondent should not be invited to join the proceedings. Procedurally, the applicant would not be in a worse position.

The draft agreement and the explanatory report are also silent concerning interim measures, which the Court may designate under Rule 39 of the Rules of Court. Since such interim measures can only be binding on the parties to the dispute, they would obviously not bind a (potential) co-respondent before joining the case. However, once a co-respondent has been admitted to proceedings, it would become necessary that the Court extends the measures to the co-respondent. As the Court can act of its own motion, this should not cause any problems.

The consequence of a judgment finding a violation would be that the EU and the Member State(s) would be jointly responsible. ${ }^{33}$ The United Kingdom

29 CDDH-UE(2011)16, para 45.

30 D Harris, M O'Boyle, C Warbrick, and E Bates (eds), Law of the European Convention on Human Rights (Oxford University Press: Oxford, 2009), 825.

31 Ibid at 825 .

32 Pisano v Italy [GC], no 36732/97, 24 October 2002.

$33 \mathrm{CDDH}(2011) 009$, para 54. 
proposed that the ECtHR should be allowed to give judgment against an individual respondent or co-respondent only where the parties jointly notify the Court that such a differentiated judgment is appropriate. ${ }^{34}$ This seems to have been accepted by most other Member States in discussions within the Council of Ministers. ${ }^{35}$ However, this proposal should be viewed critically. It would be highly problematic to give the ECtHR competence to decide on the internal division of responsibility between the EU and its Member States since such decisions are reserved to the ECJ. ${ }^{36}$ Furthermore, it is problematic from a procedural point of view if such a decision is made without the approval of the applicant. After all, once a party has agreed to become co-respondent, there should not be a possibility for either respondent or co-respondent to escape their responsibility. It would be better if an internal mechanism for resolving questions of ultimate responsibility, ie of who should have to pay a possible "just compensation' awarded by the ECtHR, were created.

The following critical appraisal is preceded by a brief description of the mechanics of the mechanism, which addresses both cases in which the EU becomes co-respondent and cases in which a Member State becomes co-respondent.

\section{(ii) The EU as Co-respondent}

Where an application is initially directed against a Member State, the EU may become co-respondent where a provision of EU law might be in violation of Convention rights.

The substantive test to be carried out by the ECtHR asks it to assess whether the applicant's allegations call into question the compatibility of a provision of EU law with the Convention. The wording of that provision as well as the explanatory report to the draft agreement suggest that 'a provision' of EU law can mean a provision of either primary or secondary law. This is remarkable given one of the rationales for the co-respondent mechanism is to account for the situation in which acts of the Union's institutions are implemented by the Member States. ${ }^{37}$ Since only the EU can remove a violation found in its own secondary law, extending the binding reach of the judgment is apposite. With regard to primary law implemented by the Member States, however, that rationale does not seem to apply since primary law is agreed upon by the Member States as well. It is not clear from the drafting history whether obligations arising from primary law were included deliberately or whether they 'slipped in'. The very first draft referred to 'legal acts or measures of the European Union'. ${ }^{38}$ This

\footnotetext{
${ }^{34}$ UK non-paper on the draft agreement, Council of the EU doc no 1563/11, which proposes the inclusion of Art 3(7) providing for such a possibility.

35 Council of the EU, doc no $16385 / 11$, p 5.

36 cf Opinion 1/91, [1991] ECR I-6079, paras 34-35; Lock, n 15, 1043.

37 CDDH-UE(2011)16, para 32.

38 CDDH-UE(2011)04.
} 
formulation was narrower and seemed restricted to secondary legislation and other measures by the EU's institutions. The next draft included the reference to 'European Union law' as one can find it in the final draft agreement. ${ }^{39}$ There is no reference in the explanatory report why this change was made. This is regrettable for an explanation would have improved our understanding of the mechanism.

But there is further room for criticism. The unambiguous requirement that the applicant's allegation calls into question the compatibility of a provision of EU law with the Convention is unfortunately obfuscated by the subordinate clause following it, which states that this would notably be the case where the violation could only be avoided by disregarding an obligation under EU law. The adverb 'notably' would suggest that 'disregarding an obligation under EU law' constitutes a sub-category of the general requirement 'compatibility of a provision of EU law with the Convention'. By referring to 'an obligation' the draft does not make it sufficiently clear whether this obligation is an obligation contained in the allegedly incompatible provision of EU law or whether it can be any obligation under EU law. A comparison with Article 3(3) of the draft agreement shows that the provision could have been drafted much clearer with Article 3(3) stipulating that 'a violation could only have been avoided by disregarding an obligation under those instruments [emphasis added]'. It is suggested that Article 3(2) should be understood in the same manner, ie that the co-respondent mechanism should apply notably where the violation could only be avoided by disregarding an obligation under that provision.

For the Court, the test to be carried out is only cursory. It merely needs to be satisfied that it is plausible that it 'appears' that the applicant's allegations call into question the compatibility of a provision of EU law with the Convention. This, it is suggested, would normally be the case wherever an applicant makes an argument to that effect unless that argument is outlandish. If in such a case the EU expresses its wish to join the proceedings as co-respondent, the ECtHR will normally have to accede to that wish.

\section{(iii) Member States as Co-respondents}

The co-respondent mechanism will also operate where the application is directed against the EU as respondent. The Member States can become co-respondents in such cases if the compatibility of a provision of primary EU law with the Convention is in question. This is obviously a reference to the situation in the Matthews case and an acknowledgement of the fact that only the Member States are capable of remedying the violation. After all, if a provision contained in the Treaties is held to be in violation of the Convention, it would need to be amended according to Article 48 of the Treaty on European Union (TEU). Thus making the Member States co-respondents in such a case

\footnotetext{
${ }^{39}$ CDDH-UE(2011)06.
} 
makes sense in order to ensure an effective and efficient human rights protection. A point on which neither the draft nor the explanatory report are unambiguous, however, is whether it is necessary that all Member States ask the ECtHR to be joined as co-respondents or whether it suffices if only some of them (or indeed one of them) do. Judging from the mechanism's rationale, only an involvement of all the Member States would ensure that the judgment could be executed against all of them, which would be necessary in order to secure a Treaty amendment. On the other hand, such a requirement would leave the mechanism almost unworkable given that all twenty-seven Member States would have to have expressed their wish to join proceedings before proceedings are finished. ${ }^{40}$ Were the ECtHR to wait until all Member States have declared whether they wish to join, proceedings might be unduly delayed. In addition, another rationale of the co-respondent mechanism might be served even by having only some Member States join proceedings: they would be able to defend the case from the point of view of the Member States. Moreover, a systematic argument can be made. For cases in which proceedings are instigated against the EU and one or more of its Member States, Article 3(4) of the draft agreement allows for a change of status of any respondent to that of co-respondent, ie it allows for a change of status of one Member State to that of co-respondent alongside the EU as (main) respondent. Since the conditions for becoming co-respondent under Article 3(4) are the same as under the other provisions save for the fact that the co-respondent was initially nominated as a (main) respondent, there should be no material difference. This suggests that it is admissible under Article 3(3) if only some Member States ask the Court to join proceedings.

One might be tempted, however, to raise two questions regarding the sensibility of the co-respondent mechanism in the scenario foreseen in Article 3(3) of the draft. The first question is why the EU should be held responsible for violations of the Convention by primary law in the first place. After all, it is unable to remove such violations without the consent of the Member States. ${ }^{41}$ There are three arguments which can be advanced in favour of such responsibility. The first relates to the aim of the accession agreement which is to treat the $\mathrm{EU}$ as far as possible like any other party to the Convention. ${ }^{42}$ As a result, it should be responsible for violations of the Convention rooted in its own constitutional documents. Furthermore, excluding the EU's responsibility for primary law would force the ECtHR to decide in each and every case brought against the EU where exactly the violation was located, which might conflict

\footnotetext{
${ }^{40}$ On the last possibility to make a request, cf above.

41 This seems to have been the argument made by the French government which initially opposed a responsibility of the EU for its primary law: French Senate, Communication de M. Robert Badinter sur le mandat de négociation (E 5248) 25 May 2010, available at: < http://www.senat.fr/europe/ r25052010.html\#tocl > accessed 13 December 2011.

42 Explanatory report, CDDH-UE(2011)16, para 7.
} 
with the autonomy of the EU's legal order. ${ }^{43}$ The final argument is that even though the EU cannot amend its own Treaties, its institutions are still involved in the amendment procedure laid down in Article 48 TEU. Extending the binding reach of a judgment to the EU's institutions is thus wise. Thus there are good legal and symbolic arguments for the EU's responsibility for its own primary law.

But this does not answer the second question why the role of the Member States should be that of co-respondents rather than that of 'ordinary' respondents. As explained above, one of the main motivations for devising the co-respondent mechanism was to prevent the need for a decision on the division of competence between the EU and its Member States. Yet in the case of primary law this aim could equally have been attained by bringing a case against both EU and Member States as 'ordinary' respondents since it would not be necessary for the ECtHR to pronounce on that question as both EU and Member States would be fully responsible. But it seems that another aspect of the co-respondent mechanism was decisive: there is no need to exhaust domestic remedies in the co-respondent's legal order. At first glance, this rationale seems odd as we are dealing with primary EU law against which there is not normally a domestic remedy. But there are some Member States which recognize a possibility to challenge the compliance of the Treaties with the Member State's constitution. ${ }^{44}$ Thus the extension of the co-respondent mechanism to these types of situations can pre-empt an argument by a joint respondent that the applicant failed to exhaust remedies in its legal order.

\section{(iv) Appraisal of the Co-respondent Mechanism}

Apart from the issues raised in the preceding paragraphs, some general points will be made in this section. They relate to the voluntary character of the co-respondent status, the division of responsibility between EU and Member States after accession, and problems surrounding cases alleging a violation of the ECHR by omission.

\section{Voluntary Character}

The draft is explicit about the voluntary character of the co-respondent mechanism when it states that a party shall become co-respondent only at its own request. The rationale given in the explanatory report is that a party cannot be forced into proceedings where it was not named in the initial application. ${ }^{45}$ Yet

\footnotetext{
43 Lock, n 15, 1038.

${ }^{44}$ For instance, the Verfassungsbeschwerde before the German Federal Constitutional Court can under certain conditions serve to that end.

45 CDDH-UE(2011)16, para 47.
} 
this argument is based on a mere technicality and is hardly convincing. ${ }^{46}$ There is no reason why an applicant should not ask another party to join proceedings at a later stage provided that the procedural rights of that party are respected, especially regarding their right to be heard.

Moreover, it is argued that the draft partly contradicts the rationale for the co-respondent mechanism. According to the explanatory report, the main reason for its introduction is to avoid gaps in the participation, accountability, and enforceability in the Convention system. ${ }^{47}$ But a voluntary mechanism leads to exactly such gaps. The EU or a Member State may well decide to steer clear of proceedings even though they would be responsible for the alleged violation. The fact that the applicant can nominate both from the outset does not remedy this problem since it would force the applicant to exhaust domestic remedies in all legal orders concerned, which is not only costly but also time-consuming. It should especially be borne in mind that an applicant before the ECtHR does not need to be represented by a lawyer so that she may not even be remotely aware of these requirements. It follows that the current draft only achieves sub-optimal results regarding the efficiency of human rights protection for individuals.

There is furthermore the danger that a Member State raises the defence that it was not responsible for the violation as the violation was rooted in its obligations under EU law and it had no discretion. The draft and the explanatory report are silent regarding this possibility. It is important that the ECtHR would not accept such a defence. Otherwise, the human rights protection as regards EU law would risk being less effective than it is now. It is suggested that the draft presupposes that no such defence should be possible. But lacking an explicit statement to that effect, there is no guarantee that this will be the case.

Moreover, one can doubt that the voluntary character of the co-respondent status is fully in compliance with Protocol 8 to the Lisbon Treaty. After all, that Protocol demands that the accession agreement should 'ensure' that individual applications are correctly addressed to the EU or the Member States as appropriate. If the status of co-respondent is voluntary, it is not guaranteed that cases are addressed to the entity which is really responsible for the violation. Of course, the internal rules on the EU's membership of the ECHR are still not clear. But even if these rules provide for a duty on the part of the EU to become co-respondent in cases where the alleged violation is found in EU law, such a solution would be unsatisfactory as it would entrust the co-respondent, who has allegedly committed a violation of human rights, with the assessment of whether it should join proceedings or not. There would still be no way of

\footnotetext{
46 This author has voiced considerable criticism of the voluntary character of the status of co-respondent elsewhere, of T Lock, 'EU Accession to the ECHR: Implications for Judicial Review in Strasbourg' [2010] ELRev 777, 793.

${ }_{47} \mathrm{CDDH}-\mathrm{UE}(2011) 16$, para 33.
} 
forcing the EU to join as co-respondent and an applicant might be left without effective protection.

\section{Division of Responsibility Post-Accession}

Having outlined the different facets of the co-respondent mechanism, it is apt to enter into a thought experiment in order to predict the division of responsibility between EU and Member States post-accession and in order to assess the practical relevance of the co-respondent mechanism. For this purpose, a hypothetical case study will be conducted consisting of scenarios which in the past gave rise to ECtHR decisions relating to EU law and scenarios likely to reach the ECtHR at some point after accession.

If the accession agreement is adopted in its current form, the main issue for deciding who is responsible will be the question of jurisdiction. Article 1 ECHR provides that the High Contracting Parties secure to everyone within their jurisdiction the rights and freedoms contained in the ECHR. It follows that the EU would only be responsible where an alleged violation occurred within its jurisdiction. The same would be true for the Member States. Both EU and Member State would thus only be responsible alongside one another where the alleged violation occurred in the jurisdiction of both. It is therefore necessary to briefly explain what is meant by the term 'jurisdiction'. The ECtHR understands the concept of jurisdiction as a concept of international law. ${ }^{48}$ Jurisdiction in international law is commonly defined as the authority of the State to regulate the conduct of persons by means of its own domestic law. ${ }^{49}$ If this concept of jurisdiction is equally applied to the EU, a person would be in its jurisdiction where an EU act, be it legislative, executive, or judicial, regulates their conduct. This means in effect, that wherever EU law is applicable, a person is within the jurisdiction of the EU. ${ }^{50}$ As the case-law on the Member States' responsibility for EU acts shows, situations can occur where the Member States would be responsible as well. This is either the case where the Member States have implemented EU legislation ${ }^{51}$ or where a court of a Member State has made a preliminary reference to the ECJ. ${ }^{52}$ Reflecting this, the explanatory report to the draft agreement mentions three cases 'which might have certainly required the

48 Bankovic and others v Belgium, the Czech Republic, Denmark, France, Germany, Greece, Hungary, Iceland, Italy, Luxembourg, the Netherlands, Norway, Poland, Portugal, Spain, Turkey and the United Kingdom [GC], no 52207/99, ECHR 2001-XII, para 57; recently confirmed in Al-Skeini and others v United Kingdom, no 55721/07, 7 July 2011, para 131.

49 V Lowe, International Law (Oxford University Press: Oxford, 2007), 170; M Milanovic, 'From Compromise to Principle: Clarifying the concept of state jurisdiction in human rights treaties' [2008] HRLR 411, at 420; Milanovic is highly critical of the ECtHR's adoption of this definition and argues that it is too restrictive for a human rights treaty by being primarily based on territory.

${ }^{50}$ In the discussions following the adoption of the draft, the United Kingdom made a proposal to clarify what 'jurisdiction' means in regard to the EU, cf Council of the EU, doc no 16385/11. This does not seem necessary given the ECtHR's case-law on the matter.

${ }^{51}$ Bosphorus, n 12.

52 Kokkelvisserij $v$ Netherlands, no 13645/05, 20 January 2009. 
application of the co-respondent mechanism'. ${ }^{53}$ They are Matthews, ${ }^{54}$ Bosphorus, ${ }^{55}$ and Kokkelvisserij. ${ }^{56}$ The factual scenarios underlying these cases will be used to illustrate the functioning of the co-respondent mechanism.

As a preliminary point, it is obvious that in cases like Connolly where there was no Member State involvement, nothing will change: they will remain outside the Member States' jurisdiction, so that only the EU will be responsible. As explained above, the mechanism presupposes that the Member States continue to be responsible for violations of the Convention brought about by EU law where they implemented such legislation whether they had discretion or not. Otherwise accession by the EU to the ECHR as conceived in the draft agreement would lead to new gaps in the human rights protection, which accession aims at removing.

In a scenario like Bosphorus, where a Member State implemented an EU Regulation, the action would occur within the respondent Member State's jurisdiction so that it would remain responsible for the violation. The EU would be free to join proceedings as a co-respondent. A different question is, however, whether under the new rules the applicant could choose not to hold the implementing Member State responsible in a Bosphorus-type scenario but the EU instead arguing that the legislation as such was in violation of the applicant's Convention rights. Firstly, the applicant would have to be within the jurisdiction of the EU according to Article 1 ECHR. Considering that an EU Regulation is directly applicable and thus regulates the conduct of persons on the territory of the EU (ie in the Member States) this would be the case. Second, in order to bring an admissible application, the applicant would have to be a victim of a violation according to Article 34 ECHR. This would be more problematic here since the applicant would bring the case against a piece of legislation and not an implementing act. For a person to be considered a victim where there is no implementing act, the ECtHR requires that a provision applies automatically, ie without further implementation ${ }^{57}$ or that its very existence continuously and directly affects the individual. ${ }^{58}$ It follows that where a provision merely grants national authorities the power to act, the applicant would not normally be considered a victim since his legal position is only affected once this power is used. Bosphorus is a case in point. The mere existence of a power of Member State authorities to impound an aircraft would not have affected Bosphorus' right to property. Only once the authorities had made the order to impound the aircraft were the carrier's rights affected. Thus post-accession an applicant in the same situation as Bosphorus would not be able to bring a case

53 CDDH-UE(2011)16, fn 18.

54 Matthews, n 11.

55 Bosphorus, n 12.

56 Kokkelvisserij, n 52.

57 Marckx v Belgium, no 6833/74, Series A no 31, para 27.

58 Dudgeon v United Kingdom, no 7525/76, Series A no 45, para 41. 
directly against the EU, but would have to address it to the Member State. The Bosphorus scenario is thus a prime example of a case in which the involvement of the EU as co-respondent makes sense. This is confirmed by the wording of Article 3(2) of the draft agreement, which says that the co-respondent mechanism would notably apply where the violation could have been avoided only by disregarding EU law. ${ }^{59}$

However, there is no requirement in the wording of Article 3(2) of the draft agreement that there must not be any Member State discretion. This is confirmed by the drafting history of the provision. In contrast to the first revised draft, which was clearly modelled on Bosphorus ${ }^{60}$ and required the existence of a normative conflict between a Member State's obligations under EU law and under the ECHR, no such requirement is contained in the final version of the draft agreement on accession. Since many EU law obligations leave a degree of discretion to the Member State, there are potentially a lot more cases capable of engaging the $\mathrm{EU}$ as co-respondent than if the co-respondent mechanism had been restricted to cases where there was no Member State discretion. ${ }^{61}$

The facts underlying the recent M.S.S. case, however, show that the co-respondent mechanism would not be applicable in all cases where a Member State has implemented its obligations under EU law. ${ }^{62}$ The applicant was an asylum-seeker who entered the EU via Greece and applied for asylum in Belgium. On the basis of Article 10(1) of the EU's Dublin Regulation, ${ }^{63}$ Belgium sent him back to Greece since it is the responsibility of the Member State through which the asylum-seeker first entered the EU to examine his application for asylum. ${ }^{64}$ The ECtHR quoted the Dublin Convention and other EU law among the 'relevant law' for its decision. But a request by the EU to be admitted as co-respondent would not have been allowed since the compatibility of the Dublin Regulation with the Convention was not at issue in the proceedings. The applicant only claimed that his treatment by Greece and Belgium violated the Convention. No argument was made regarding the compatibility of the Dublin Regulation and there was no reason to assume that the relevant provisions of the Dublin Regulation fell foul of the standards required by the ECHR. The M.S.S. case shows that the co-respondent mechanism will normally only be engaged where an applicant claimed that the legal basis for Member State action contradicts the ECHR. Thus, for instance, in a case

\footnotetext{
59 Emphasis added.

60 Article 4, CDDH-UE(2011)06, which requires for the co-respondent mechanism to apply that '[...] an act or omission underlying an alleged violation notified could only have been avoided by disregarding an obligation under [EU] law [...]'.

61 A further question would be whether the ECtHR should continue its Bosphorus presumption. There are good arguments that it should not, cf Lock, n 46, 797.

62 M.S.S. $v$ Belgium and Greece [GC], no 30696/09, 21 January 2011.

63 Council Regulation 343/2003/EC [2003] OJ L 50/1.

${ }^{64}$ As was rightly noted by the ECtHR, Belgium was not under a strict obligation to send back the applicant. It could have decided to investigate the case itself but chose not to do so, M.S.S., para 339.
} 
brought against an EU Arrest Warrant, the involvement of the EU would depend upon whether the applicant also alleges that the Council's Framework Decision 2002/584/JHA was also in violation of the ECHR and not only its application by the Member State's authorities. The only way of involving the EU in cases like M.S.S. would be as a third-party intervener. ${ }^{65}$

In contrast to Bosphorus and M.S.S., the Matthews case dealt with the responsibility of a Member State for a provision of EU primary law. The applicant complained against not being able to register as a voter in the elections to the European Parliament. Her application to that effect had been rejected by the authorities of Gibraltar whose actions were attributable to the United Kingdom. In the original case, the United Kingdom was held responsible for the violation as the European Community's 1976 Act on Direct Elections was part of primary EU law, for which the Member States are responsible. If a case like Matthews arose after accession, the applicant would still be able to hold the Member State responsible as the rejection to add her to the electoral register must be considered an implementing act so that the alleged violation would occur within the jurisdiction of the Member State. But the violation would equally occur within the jurisdiction of the EU. In contrast to the situation in Bosphorus, the applicant would also be the victim of a violation by the EU since the 1976 Act directly determined her legal position. The applicant would thus have a choice as to whom to hold responsible. As regards the co-respondent mechanism, the $\mathrm{EU}$ would be eligible to become co-respondent where the case is brought against a Member State. Equally, where the case is brought against the EU, one or more Member States would be able to become co-respondents. ${ }^{66}$

A provision of primary law which is likely to come under attack after accession is Article 263(4) TFEU. It allows individuals to challenge acts of the EU institutions where an act is addressed to them, where it concerns them directly and individually, or where it is a regulatory act which entails no implementing measures. In its famous UPA ruling, the ECJ confirmed its old case-law ${ }^{67}$ that an applicant is only individually concerned where she belongs to a 'closed group' of applicants, ie persons with 'certain attributes peculiar to them, or by reason of a factual situation which differentiates them from all other persons and distinguishes them individually in the same way as the addressee. ${ }^{68}$ Under ex Article 230(4) TEC, this meant that where there was an act which did not entail implementing measures, ie which was self-executing, it could not be directly challenged by an affected individual before the ECJ. In UPA the ECJ argued that this was not in violation of the right to an effective remedy guaranteed by

\footnotetext{
65 The explanatory report states that the third-party intervention 'may often be the most appropriate way to involve the EU', CDDH-UE(2011)16, para 40.

${ }^{66}$ On the question whether all of them would have to become co-respondents, cf above.

67 Starting with Case 25/62, Plaumann v Commission [1963] ECR 95.

68 Case C-50/00 P, Unión de Pequeños Agricultores [2002] ECR I-6719, para 36.
} 
Articles 6 and 13 ECHR despite severe doubts as to that result raised by Advocate General Jacobs. ${ }^{69}$ The Lisbon Treaty made an attempt at plugging this potential hole in the judicial protection of individuals by introducing a right to challenge 'regulatory acts' which do not entail implementing measures. But according to a recent decision by the General Court regulatory acts are non-legislative acts, ${ }^{70}$ so that in cases where eg a Council regulation does not require implementing measures, there is still no possibility for an individual to directly challenge it before the ECJ. Were an unsuccessful applicant to bring a case to the ECtHR claiming violation of Articles 6 and 13 ECHR, she would only be able to bring the case against the $\mathrm{EU}$ as the main respondent since due to a lack of an implementing measure the violation did not occur in the jurisdiction of the Member States. ${ }^{71}$ They would, however, be able to join as co-respondents.

Kokkelvisserij, the final case in this analysis, differs from the previously mentioned cases. The applicant cooperative essentially alleged a failure to legislate and did not claim that a provision of EU law restricted it in its rights. The applicant argued that it should have been given an opportunity to respond to the submissions of the Advocate General before the ECJ, which allegedly violated its right to a fair trial guaranteed by Article 6 ECHR. It argued in particular that Article 61 of the ECJ's Rules of Procedure granted the ECJ discretion over the reopening of the oral procedure which was in violation of the Convention since it deprived the applicant of a guaranteed right to respond. In essence, the applicant therefore argued that the Rules of Procedure were insufficient and violated the Convention. The Rules of Procedure are of a sui generis legal nature since they are laid down by the Court itself with the approval of the Council. ${ }^{72}$ The case therefore dealt with an alleged violation attributable to the EU. The only reason why the ECtHR considered that the alleged violation occurred within the respondent State's jurisdiction was that a domestic court had made a request for a preliminary ruling to the ECJ under Article 267 TFEU. Assuming that an EU Member State would still be responsible in cases which came before the ECJ by way of a preliminary reference after accession, the question is whether the EU would be able to become co-respondent. Since the Rules of Procedure, despite their sui generis nature, must be regarded as 'a provision of European Union law' the compatibility of which with the Convention was in question, on a strict reading of the wording of Article 3(2) of the draft agreement the co-respondent mechanism would have been applicable. But the scenario in Kokkelvisserij is anomalous for two reasons:

\footnotetext{
${ }^{69}$ Case C-50/00 P, Unión de Pequeños Agricultores [2002] ECR I-6681, Opinion of AG Jacobs.

70 Case T-18/10, Inuit Tapiritt Katanami v Parliament and Council, 6 September 2011, paras 36-56 (under appeal as Case C-583/11).

${ }_{71}$ This would be similar to Connolly, above.

72 B Wegener, 'Art. 253 AEUV' in C Calliess and M Ruffert (eds), EUVIAEUV (CH Beck: München 2011), para 8.
} 
first, the only reason why the Member State could be taken to the ECtHR was that its own domestic court had requested a preliminary ruling. Had the case come before the ECJ by way of a different procedure, the Member State would not have been responsible. Second, there was already some (allegedly insufficient) legislation in place, the compatibility of which with the ECHR was in question. Thus the question of compatibility of that legislation with the Convention could be raised which is one of the preconditions for the involvement of a co-respondent. Yet in cases where not even insufficient legislation exists, it would be questionable whether the co-respondent mechanism would apply.

The example of Kokkelvisserij thus brings us to the more general question of how alleged violations by omission would be dealt with after accession.

\section{The Case of Omissions}

It is well established in the case-law of the ECtHR that the Convention is not only violated where a High Contracting Party actively interferes with an individual's rights but also where it fails to act provided that the Convention contains a positive obligation to do so. ${ }^{73}$ Cases concerning the EU can either deal with alleged failures to legislate or with failures by the executive to act. The latter would be relatively unproblematic. Where an applicant alleges that one of the EU's institutions has failed to act, the addressee of a subsequent application to the ECtHR would clearly be the EU. ${ }^{74}$ But where failures to legislate are concerned, the correct addressee cannot easily be determined. The problem with legislative competences is that they are divided between the EU and its Member States so that both could potentially be held responsible in the ECtHR. The provisions in the draft agreement do not specifically mention omissions but it is clear from its preamble and the explanations to it that violations of the ECHR by omission are covered, too. ${ }^{75}$

The problem is that strictly speaking, the Member States are not responsible for violations of the Convention by omission where the EU had the exclusive competence to act. The reverse is true for the EU where the Member States had the exclusive competence to act. If such a case came before the ECtHR, the Court might therefore be prompted to investigate the division of competences between EU and Member States. However, such an investigation would violate the autonomy of EU law as it would necessitate a binding interpretation of EU

\footnotetext{
73 eg Artico v Italy, no 6694/74, Series A no 37, para 33; Marckxv Belgium, no 6833/74, Series A no 31, para 31; Gaskin v UK, no 10454/83, Series A no 160, para 41; Airey v Ireland, no 6289/73, Series A no 32, paras 31-33; $X$ and $Y v$ The Netherlands, no 8978/80, Series A no 91, paras 24-30; López Ostra v Spain, no 16798/90, Series A no 303-C, para 51.

74 The applicant would of course be required to first exhaust the remedy provided in Art 265(3) TFEU.

75 Its preamble expressly recognizes the right of individuals to submit omissions of the EU to the external control of the ECtHR.
} 
law by the ECtHR. ${ }^{76}$ This could be avoided if the co-respondent mechanism were to ensure that both could be held responsible.

Yet the formulation in the article concerning the co-respondent mechanism does not seem to cover all potential cases in this respect. In order to show this it is necessary to distinguish different scenarios in which an applicant may allege a violation of his Convention rights by omission. One scenario concerns cases where a provision of EU law mandates action by a Member State. In such a case, the applicant can hold the Member State responsible for a failure to comply. The EU would not be able to become co-respondent since EU law would not be challenged. Another scenario would concern cases where no legal provision exists, either at EU level or at Member State level. This scenario would differ from that in Kokkelvisserij where by coincidence there was already some legislation in place which the applicant argued insufficiently protected her rights. However, on a literal reading the mechanism would be inapplicable since in this scenario no claim would be made that a provision of EU law was not in compliance with the Convention since the non-existence of such a provision is the problem. Thus there is a lacuna in the provision concerning the co-respondent mechanism which raises doubts as to the compliance of the draft agreement with Article 1 of Protocol 8 to the Lisbon Treaty, which demands that the accession agreement should ensure that applications are addressed to the correct entity. With regard to cases of alleged omissions to legislate arising outside the rather specific circumstances of Kokkelvisserij the draft agreement fails to deliver on this point.

\section{Overall Comment}

The preceding analysis has shown that the division of responsibility between the EU and the Member States after accession will not always be easy to determine. This is largely due to the ECtHR's understanding of jurisdiction and the limitations of the co-respondent mechanism, especially regarding its voluntary nature. The consequence is that the determination of the correct respondent can at times appear random. This is probably best illustrated by the peculiar set of facts in the Kokkelvisserij case, where the only reason why a Member State could be held responsible for an alleged procedural deficit of an EU institution (the Court of Justice) was because the case had reached the ECJ by way of a preliminary reference. While this is a less serious issue, the question of who should be responsible for legislative inaction remains largely unresolved. A differently designed co-respondent mechanism would be capable of addressing all these points. Two changes would appear appropriate. First, the co-respondent should not be allowed to refuse being joined to proceedings. Second, the scope of application of the mechanism ought to be extended: wherever a question of EU law arises, the respondent should be able to request a potential

76 cf Opinion 1/91 [1991] ECR I-6079, paras 34-35. 
co-respondent to join. This would avoid gaps in the responsibility and, importantly, it would remove the danger of the ECtHR delineating the competences between EU and Member States. ${ }^{77}$

\section{B. Prior Involvement of the ECJ where the EU is Co-respondent}

A further novelty which accession will bring is closely connected to the co-respondent mechanism: the possibility of an involvement of the ECJ in such proceedings creating an institutional link between the two European courts. As has been pointed out above, one of the advantages for an applicant in cases where the EU is co-respondent before the ECtHR is that he does not need to exhaust the remedies available before the ECJ. Exhaustion of domestic remedies in the respondent Member State is sufficient. This can lead to a situation where the compatibility of a provision of EU law with the Convention is assessed without the ECJ having had a chance to pronounce on the question. Presumably, in the vast majority of cases the ECJ will have been involved via the preliminary reference procedure laid down in Article 267 TFEU, but such involvement is not guaranteed. National courts are under a duty to make a reference either where they are courts of last resort ${ }^{78}$ or, independently of their place in the hierarchy, where the validity of EU legislation is at issue since they must not infringe the ECJ's monopoly to declare such legislation void. ${ }^{79}$ But these rules are not watertight. There are a number of conceivable reasons why in situations where the co-respondent mechanism applies a national court may not have made a reference. One (unlikely) possibility is that the national court was unaware of its duty to make a reference. In a more probable scenario a national court would come to the conclusion that the provision of EU law in question was not incompatible with fundamental rights and was therefore valid. In contrast to determinations of invalidity, national courts have a right to consider provisions of EU law valid on their own devices. ${ }^{80}$ This situation might arise relatively often since the test for the applicability of the co-respondent mechanism is rather superficial: it would be sufficient for the co-respondent mechanism to apply if it appears that the applicant's allegations call into question the compatibility of a provision of EU law with the Convention. Given the tendency of counsel to support their client's case with every conceivable argument, such calling into question is prone to happen relatively often. Claims of this kind may often appear far-fetched and may thus induce the national court to ignore them. Thus there is a realistic chance that the ECtHR might rule on

\footnotetext{
77 A more detailed discussion of this proposal can be found in Lock, $\mathrm{n} 46,786$.

78 Article 267(3) TFEU.

79 Case 314/85, Firma Foto-Frost v Hauptzollamt Lübeck-Ost [1987] ECR 4199, para 15.

${ }^{80} \mathrm{Ibid}$ at para 14; under the draft agreement, the CILFIT case-law (Case 283/81 [1982] ECR 3415 ) would not play an important role since the co-respondent mechanism would only be applicable where the validity of a provision of EU law is at stake and not in cases concerning a mere interpretation of EU law.
} 
the compatibility of a provision of EU law with human rights, and thus indirectly on the validity of that provision under EU fundamental rights law, without the ECJ having had a chance to remedy the violation. ${ }^{81}$

Against this background, the Presidents of the two European Courts issued a joint communication urging for a flexible procedure allowing the ECJ to carry out an internal review before the ECtHR has carried out its external review. ${ }^{82}$ The Presidents named the principles of subsidiarity as the underlying reason for a prior involvement of the ECJ. ${ }^{83}$ This argument, however, is not compelling. While it is true that a review by the ECJ might remedy the violation and thus reduce the workload of the ECtHR, the introduction of a specific procedure guaranteeing a prior involvement of the ECJ leads to a privileging of the EU's legal order over the legal orders of other parties to the Convention. The fact that the ECJ may not get involved in some cases is down to a deficit of protection in the EU's legal order in that there is often no possibility for an individual to have the legislation at issue reviewed in any other way but by a preliminary reference. ${ }^{84}$ If the EU considers this to be problematic it should try to fix the problem within its own legal system. Moreover, there are parties to the ECHR where a similar situation to that of the EU exists. For instance, in Italy there is no direct access to the Italian Constitutional Court for individuals but only indirect access through another court. But there is no special procedure before the ECtHR to accommodate for this. Thus there have been cases in which an individual was able to file an admissible application to the ECtHR against Italy without a previous decision of the Constitutional Court. ${ }^{85}$ The prior involvement seems to go against this spirit.

The drafters of the accession agreement apparently did not share these concerns and adopted the position of the two presidents. ${ }^{86}$ The accession agreement contains the following Article 3(6):

In proceedings to which the European Union is co-respondent, if the Court of Justice of the European Union has not yet assessed the compatibility with the

81 Of course, the number of cases would still be low as the application of the co-respondent mechanism and thus of the prior involvement mechanism would depend on the case actually being communicated, cf above.

82 Joint communication from the Presidents Skouris and Costa <http://curia.europa.eu/jcms/ upload/docs/application/pdf/2011-02/cedh_cjue_english.pdf $>$ accessed 13 December 2011; similar arguments were advanced previously, eg by former ECJ Judge Timmermans, L'adhésion de l'Union Européenne à la Convention européenne des Droits de l'homme, intervention at a hearing before the European Parliament's Committee on Constitutional Affairs, 18 March $2010<$ http://www.euro parl.europa.eu/document/activities/cont/201003/20100324ATT71235/20100324ATT71235EN .pdf $>$ accessed 13 December 2011.

83 Ibid.

84 The only possibility is the (still) rather narrowly phrased Art 263(4) TFEU.

85 Article 134 of the Italian Constitution and legge costituzionale 9 febbraio 1948 , n 1; Brozicek $v$ Italy, no 10964/84, 19 December 1989; Immobiliare Saff, no 22774/93, 28 July 1999; de Jorio v Italy, no 73936/01, 6 March 2003.

${ }^{86}$ CDDH-UE (2011)16, para 58. 
Convention rights at issue of the provision of European Union law as under paragraph 2, then sufficient time shall be afforded for the Court of Justice of the European Union to make such an assessment and thereafter for the parties to make observations to the Court. The European Union shall ensure that such assessment is made quickly so that the proceedings before the Court are not unduly delayed. This paragraph shall not affect the powers of the Court. ${ }^{87}$

This draft provokes three questions: (1) which circumstances trigger the procedure; (2) what should be the procedure before the ECJ; and (3) what are consequences of the ECJ's decision for the proceedings before the ECtHR?

\section{(i) Circumstances Triggering the Prior Involvement}

It is clear from the wording of the provision that there can only be a prior involvement in cases where the EU is co-respondent. But this provokes the question of how to deal with a situation where both the EU and the Member State are 'normal' respondents. Such a situation can arise where the applicant nominates both as respondents from the outset and the EU does not opt to become co-respondent. ${ }^{88}$ As we have seen, in such a case the applicant must exhaust the domestic remedies in the Member State and in the EU. Thus one might think there cannot be an issue. However, where, for instance, the applicant's case is based on a violation of the Convention brought about by an EU Directive or by primary law, she has no domestic remedy under EU law. ${ }^{89}$ If in the proceedings before the court of the Member State the national court does not make a reference to the ECJ, the case would be decided by the ECtHR without an involvement of the ECJ. This solution compares oddly to a situation in which the EU is co-respondent since in such a case the ECtHR would have to give the ECJ the opportunity to make a decision, the only difference between the two cases being the status of the EU in the proceedings. One could, of course, consider applying the co-respondent mechanism by analogy. But it is submitted that this would privilege the EU even more since it is entirely in its own hands to decide that it wishes to be a co-respondent which would bring with it the 'perk' of having the case reviewed by the ECJ as well. This would not only be compatible with the wording of the provision on prior involvement but also in comparison with cases in which the EU is the sole respondent. ${ }^{90}$ Here,

\footnotetext{
87 CDDH-UE(2011)10.

88 This argument assumes that a situation is conceivable where a 'victim' according to Art 34 ECHR can be in the jurisdiction of the EU and of a Member State at the same time.

89 Where Regulations are concerned, the latest case-law of the General Court on the newly formulated Art 263(4) TFEU suggests that she would not have a remedy either, cf Case T-18/10, Inuit Tapiritt Katanami v Parliament and Council, 6 September 2011, not yet reported, para 39 et seq; Case T-262/10, Microban v Commission, 25 October 2011, not yet reported, para 21.

90 Admittedly, in cases where there is implementing action by a Member State it would be strategically inadvisable to hold only the EU responsible since it may well have happened that the Member State added another violation when implementing the provision of EU law.
} 
too, the applicant need only exhaust the domestic remedies available under EU law, of which there may be none available to her. Thus the prior involvement should only occur in strict accordance with the wording of Article 3(6) of the draft.

Regarding the substantive requirement, the ECJ may be involved where it 'has not yet assessed the compatibility with the Convention rights at issue of the provision of European Union law'. This requirement points to a further complication in that it does not simply ask whether the ECJ has ruled in the case, but whether the ECJ has also assessed the rights at issue. The background appears to be that under the preliminary reference procedure, the ECJ is limited to answering the questions put before it, which may not have dealt with the compatibility of the provision with the fundamental rights. In such a situation, a further involvement of the ECJ may thus be required. But under which exact circumstances must the ECJ be deemed to have pronounced on the Convention rights at issue? Since the ECJ will normally base its findings on the rights contained in the Charter of Fundamental Rights and not directly on the Convention, further analysis will become necessary. In making its decision whether to involve the ECJ, the ECtHR will need to scrutinize a prior preliminary ruling as to whether the discussion by the ECJ in substance dealt with the Convention rights at issue in the case before the ECtHR. But it is submitted that the ECtHR's task will not be too onerous. While the question of corresponding rights between Charter and Convention is somewhat debated, ${ }^{91}$ with regard to the necessity of a prior involvement of the ECtHR it will only have to assess whether the rights protected in the ECHR have been substantively covered by the ECJ. This examination is comparable with that carried out by the ECtHR when dealing with the exhaustion of domestic remedies. The Court already requires applicants to raise all their grievances before the national instances. As far as they fail to do so, their complaint is declared inadmissible. The scrutiny to be carried out regarding the prior involvement will be substantially the same.

\section{(ii) Procedure before the ECJ}

The draft is silent on the procedure before the ECJ where the ECJ is involved under the prior involvement provision. The details of the ECJ's involvement will have to be laid down in the EU's internal rules on ECHR membership. At the time of writing, there have not yet been any official pronouncements on the matter. It is clear, however, that the ECJ can only be given new functions as far as the autonomy of EU law permits. In this respect it is of importance that the new procedure does not lead to a hidden Treaty amendment. The ECJ summarized its autonomy case-law in Opinion 1/00 and stated in particular that 'the

91 cf Art 52(3) CFR; instructive on this question: P Craig, The Lisbon Treaty (Oxford University Press: Oxford, 2010), 232-3. 
essential character of the powers of the Community and its institutions remain unaltered'. ${ }^{92}$ A detailed discussion of this question would go beyond the remit of this paper. ${ }^{93}$ On a narrow view of the autonomy of the EU legal system, the prior involvement of the ECJ would have to be based on already established procedures since otherwise a Treaty amendment would be necessary. One way would be to allow for a prior involvement of the ECJ by putting the European Commission in charge of instigating proceedings in accordance with Article 263 TFEU. The Commission would thereby challenge the validity of the provision of EU law which appears to be incompatible with the Convention. This way, the ECJ would not be given any new powers so that there would be no conflict with the autonomy principle. And since the Commission would probably represent the EU before the ECtHR, ${ }^{94}$ it would be familiar with the case and the questions at issue and thus be in an ideal position to decide whether to involve the ECJ. But there may be issues with the two-month time limit for challenging Union acts laid down in Article 263(6) TFEU.

One could equally adopt a broader view, allowing for the creation of a new procedure for prior involvement to be laid down in the internal rules. In order not to violate the autonomy of the EU's legal order, one would have to argue that the prior involvement was implicitly authorized by Article 6(2) TEU, which mandates accession of the EU to the ECHR. At first glance, this view seems to be far-fetched. After all, Article 6(2) TEU is chiefly an external competence and can be read as a reaction to Opinion 2/94, in which the ECJ stated that an explicit competence was needed for the Union to accede to the ECHR. The wording of Article 6(2) TEU does not suggest that it also grants competence to the EU's institutions to create a new procedure for the prior involvement of the ECJ. But given that the ECJ itself has twice demanded that such a procedure be introduced, ${ }^{95}$ and given that the new procedure enhances its own powers, it is likely that it will not strike it down in a forthcoming opinion on accession.

\section{(iii) Consequences of a Decision by the ECJ}

The final question is what the consequences of a decision by the ECJ would be for the proceedings before the ECtHR. It is clear that a finding by the ECJ that a provision of EU law is compatible with fundamental rights would have no effect on the ECtHR as it cannot replace the external control exercised by

\footnotetext{
92 cf Opinion 1/00 [2002] ECR I-3493, para 12.

93 A discussion can be found in Lock, n 15, 1045 et seq.

94 The United Kingdom is reluctant to accept that the EU should be represented by the Commission in all cases, of United Kingdom non-paper, Council of the EU doc no 1563/11.

95 Discussion document on certain aspects of the accession of the European Union to the European Convention for the Protection of Human Rights and Fundamental Freedoms; Joint Communication from Presidents Costa and Skouris, both available at <http://curia.europa.eu $>$ (accessed 7 June 2012).
} 
Strasbourg. ${ }^{96}$ However, it is still open what would happen if the ECJ came to the conclusion that the provision in question was incompatible with fundamental rights and if it were to declare it void ex tunc as a consequence. The draft agreement does not address this eventuality. The main question in this connection is whether the applicant would lose his victim status with the consequence of the case becoming inadmissible. However, there is one problem with such a result: the decision by the national court which confirmed the violation would remain unaffected and would continue to stand as res judicata. Thus a mere finding by the ECJ that the provision of EU law at question was invalid would not suffice. If nothing further happened, the applicant would still have to be considered a victim for the purposes of the Convention. In contrast, where the national decisions have been revoked, eg where proceedings before the national courts are reopened, the applicant will lose her victim status. A similar situation occurred in a case before the European Commission on Human Rights (ECommHR) ${ }^{97}$ In that case a provision of national law was revoked after an applicant had been convicted on its basis. While the ECommHR ruled that the applicant had lost his victim status this was not simply because the legislation had been revoked but because the court decisions had been quashed, too. ${ }^{98}$

\section{The EU's Involvement in the Bodies of the Council of Europe}

The accession agreement foresees participation of the EU in those bodies of the Council of Europe which carry out functions with regard to the ECHR. These are the Committee of Ministers and the Parliamentary Assembly of the Council of Europe. Since in contrast to all other parties to the ECHR, the EU will not become a party to the Council of Europe it will not automatically be represented in those bodies and rules for the EU's involvement needed to be drawn up.

The ECHR assigns a number of functions to the Council of Europe's Committee of Ministers. Most importantly, the Committee of Ministers supervises the execution of ECtHR judgments and of friendly settlements. ${ }^{99}$ In order to allow the EU to partake in the Committee of Ministers for the purposes of the Convention, Article 7 of the accession agreement provides that the EU shall have a vote in these matters. The drafters realized that there might be a problem with block voting in cases where the supervision of a judgment against the EU, either alone or together with a Member State, is on the agenda. The background is that after accession the EU and its Member States will command twenty-eight out of forty-eight votes in the Council of Ministers allowing it to block every

\footnotetext{
96 The accession agreement explicitly stipulates that the procedure before the ECJ cannot be considered 'another procedure of international investigation or settlement' under Art 35(2)(b) ECHR, cf Art 5 of the draft.

97 Sert v Turkey, no 17598/90, 1 April 1992.

${ }^{98}$ A similar argument is made in an earlier draft of the explanatory report, CDDH-UE(2011)05, para 66.

${ }^{99}$ Articles 46(2) and 39(4) ECHR.
} 
decision. Coupled with the duty of loyalty, which may force the EU Member States to vote in concert with the EU in order to comply with the requirement of unity in the international representation of the Union, ${ }^{100}$ there would be a serious problem in the supervision of the execution of judgments by the EU. After all, it is unlikely that the EU would agree with a finding that it has failed to implement a judgment against it by the Strasbourg Court. Thus the agreement provides that the rules of the Committee of Ministers should be amended for this eventuality. The explanatory report reveals that in cases where a block vote by the EU is likely, a decision by the Council of Ministers should be adopted without a formal vote. ${ }^{101}$ This would mean that the voting rules would not be applied so that a majority of the non-EU Member States would suffice. This provision in the draft agreement has been the subject of much criticism notably by the United Kingdom and France since it might set a precedent with regard to other international for a in which the EU and its Member States participate jointly. ${ }^{102}$ Other Member States do not share this view and fear that otherwise the impartiality of the Committee of Ministers might be compromised. This suggests that with regard to the EU's participation in the Committee of Ministers the last word has not yet been spoken. In the eyes of this author the solution contained in the draft agreement seems workable and does not clearly undermine the EU's position as regards other agreements.

Less controversial would be the EU's participation in the Council of Europe's Parliamentary Assembly, a body which is inter alia in charge of electing the judges at the ECtHR. As the EU will have its own judge in Strasbourg, it was necessary to provide for the involvement of a delegation of the European Parliament in the Parliamentary Assembly. Article 6 of the accession agreement provides that the European Parliament is to have as many delegates as the largest national delegation. ${ }^{103}$ Further details will be subject to an agreement between the European Parliament and the Parliamentary Assembly. ${ }^{104}$

100 Opinion 1/94, WTO Agreements [1994] ECR I-5267, para 108.

101 CDDH-UE(2011)16fin, para 76; this would especially affect Rule 11 of the current rules, which provides that a $2 / 3$ majority is needed in order to refer the question of whether a party has failed to fulfil its obligations back to the Court, cf Rules of the Committee of Ministers for the supervision of the execution of judgments and of the terms of friendly settlements, adopted by the Committee of Ministers at its 964th meeting, 10 May 2006.

102 Council of the EU doc no 16385/11, pp 5-6.

103 Currently Germany, France, the United Kingdom, Italy, and Russia each have eighteen delegates. $104 \mathrm{cf}$ Art 6(2) accession agreement and statement by co-chairs of PACE-European Parliament joint informal body <http://assembly.coe.int/ASP/APFeaturesManager/defaultArtSiteView.asp?ID =991 $>$ accessed 13 December 2011 . 


\section{The effects of accession on the EU's legal order}

Having dwelt on the consequences of EU accession for the ECHR, the implications for the EU's legal order remain to be explored. The article addresses whether accession leads to a reviewability of CFSP measures through the back door, the consequences of the ECHR becoming an 'integral part' of EU law and whether decisions by the ECtHR will be binding on the ECJ.

\section{A. Review of CFSP Measures?}

As mentioned above, accession by the EU to the ECHR will close a gap in the ECtHR's jurisdiction to review EU actions and omissions. The question is whether the ECtHR's new jurisdiction would also cover EU actions and omissions adopted under the Common Foreign and Security Policy (CFSP). As Jacqué pointed out, such jurisdiction might result in an asymmetry between the control exercised by the ECJ and by the ECtHR. ${ }^{105}$ As is well known, Article 275 TFEU has largely excluded the ECJ's jurisdiction over the provisions of the CFSP and acts adopted on their basis, the only exceptions being claims by individuals regarding restrictive measures and cases concerning Article 40 TEU. Given that restrictive measures are the most likely measures under the CFSP to fall foul of human rights requirements, one may ask whether there might be any cases in practice where this asymmetry in jurisdiction might materialize. After all, most action under the CFSP is of a political rather than a legal nature. However, the newly codified Common Security and Defence Policy (CSDP) is an exception. Article 42(1) TEU provides for missions outside the Union, which according to Article 43(1) TEU includes inter alia peace-keeping, conflict prevention, and post-conflict stabilisation. Such tasks are carried out by the civilian and military authorities of the Member States, on which the Union may draw. Thus similar situations as in the case of Behrami and Saramati may occur. ${ }^{106}$ The factual scenarios underlying this decision can be used to illustrate the issues potentially facing the ECtHR as regards the CFSP.

In Behrami and Saramati the applicants argued that the respondent States were responsible for actions and omissions of their troops which formed part of the security presence in Kosovo (KFOR). The ECtHR held that the parties to the Convention could not be held responsible for these troops as they were under the command of the United Nations so that their action did not occur within the jurisdiction of the respondent States as required by Article 1 ECHR.

105 Jacqué, n 5, 1005.

106 Behrami v France and Saramati v France, Germany and Norway [GC], nos 71412/01 and 78166/01, 2 May 2007. 
The same result as regards the Member States might be reached if an operation were carried out under the auspices of the EU. ${ }^{107}$

Regarding the EU's responsibility in such cases, it may prove problematic that the types of missions described above are usually carried out outside the territory of the European Union. The recent Al-Skeini decision re-emphasized that jurisdiction is mainly a territorial concept and that a High Contracting Party can only be held responsible for extra-territorial action in exceptional cases. ${ }^{108}$ Yet two of the exceptions mentioned in Al-Skeini might be relevant to EU missions: first, situations where the host State has acquiesced to the EU exercising some of its public powers ${ }^{109}$ and second, a situation in which the EU exercises effective control of an area. ${ }^{110}$

Against this background, the question for the EU would be whether it should exclude the ECtHR's jurisdiction over such action by making a reservation to the ECHR to this effect or excluding the applicability of the ECHR to actions and omissions under Title V of the TEU, which deals with the CFSP. ${ }^{11} \mathrm{~A}$ blanket exclusion of the CFSP would potentially lead to an exclusion of jurisdiction over restrictive measures adopted under it. ${ }^{112}$ Since measures of this kind are particularly controversial from a human rights perspective, ${ }^{113}$ excluding the ECtHR's review in these cases would send a problematic signal to other Convention parties and might even induce them to reject the accession agreement. One could conceive of a more limited exclusion of the ECtHR's jurisdiction by restricting it to cases over which the ECJ has jurisdiction. This would have the advantage of avoiding the asymmetry in jurisdiction mentioned above. However such an exclusion might end up being vague and would force the ECtHR to decide whether the ECJ would have had jurisdiction over a given case or not.

Moreover, apart from these legal difficulties, a blanket exclusion of the CFSP would not be desirable. The main reason for the inclusion of Article 275 TFEU

107 cf Articles 42 TEU et seq on the Common Security and Defence Policy; but it is important to remember that the exact distribution of responsibility in cases of EU missions under the CSDP would very much depend on the particular command structure in place for each mission. This became evident in the recent Al-Jedda case in which the ECtHR distinguished Behrami and Saramati since in contrast to Kosovo, the UN had not assumed control over the implementation of the Security Council Resolutions rendered with regard to Iraq (Al-Jedda $v$ United Kingdom [GC] no 27021/08, 7 July 2011, para 83). Thus the violations were fully attributable to the United Kingdom as the State whose troops had committed them

108 Al-Skeini and others $v$ United Kingdom, no 55721/07, 7 July 2011, para 131.

109 Ibid at para 135.

110 Ibid at para 138 .

111 This has been suggested by the French government, but many other Member States thought such an exclusion to be unacceptable, cf Council of the EU doc no 16385/11, p 3.

112 Depending on the exact formulation of an exclusion, there would be potential for some debate over the exact limits of an exclusion since the restrictive measures as such would be adopted on the basis of Art 215 TFEU, which might render them reviewable.

113 A good example is the scenario in the Kadi case, Joined Cases C-402/05 P and C-415/05 P [2008] ECR I-6351. 
was to preserve the intergovernmental and political character of the CFSP and thereby the sovereignty of the Member States. This objective would not be in danger if the ECtHR were to exercise jurisdiction over violations of human rights committed under the CFSP. There is no danger of the ECtHR interfering with issues touching on the sovereignty of the Member States. Rather, such jurisdiction would remove a peculiar gap in the accountability for human rights violations existent at the moment where troops operating under the command of an international organization can escape scrutiny by the ECtHR whereas troops operating under the command of a State party to the ECHR cannot. ${ }^{114}$ Furthermore, this would not be the only case where an asymmetry in jurisdiction would exist after accession. After all, the ECtHR will be given jurisdiction to measure primary EU law by ECHR standards. In such cases, the ECJ cannot review the compatibility of primary legislation with fundamental rights either.

\section{B. The ECHR as an Integral Part of EU Law}

The question of the ECHR's status in the EU's legal order may be less obvious but is worth exploring. The main issue is whether the ECHR will be directly applicable in EU law and, if so, whether this would be of practical relevance given the protection already offered by the EU's fundamental rights laid down in the Charter of Fundamental Rights and recognised as general principles of EU law.

Under the so-called Haegeman doctrine, international agreements concluded by the EU, such as the ECHR, become 'an integral part of EU law'. ${ }^{115}$ But it does not automatically follow that they are directly applicable, ie invocable before the courts. For such effect, the ECJ's case-law demands that two further conditions are met. First, the wording, purpose, and nature ${ }^{116}$ of the agreement must not exclude direct effect. ${ }^{117}$ Second, the provision in question must be clear, precise, and unconditional. ${ }^{118}$ The ECHR would satisfy this test. It is designed to protect individual rights, which in the words of the ECtHR are not 'theoretical and illusory but practical and effective'. This implies that an individual must be able to rely on them in court. Furthermore, the human rights contained in the ECHR are clear and precise, especially when read in light of the vast case-law by the ECtHR, and need no further implementation. Thus the

\footnotetext{
114 cf Behrami and Saramati, n 106.

115 Case 181/73, Haegeman v Belgian State [1974] ECR 449.

116 Another formulation found in the ECJ's case-law is 'the spirit, the general scheme and the terms', cf Joined Cases 21/72-24/72, International Fruit Company [1972] ECR 1219.

117 Case 12/86, Demirel v Stadt Schwäbisch Gmünd [1987] 3719, para 14; such exclusion was for instance found regarding the WTO agreements, cf Case C-149/96, Portugal v Council [1999] ECR I-8395 and with regard to the United Nation Convention on the Law of the Sea, cf Case C-308/06, Intertanko [2008] ECR I-4057.

118 Demirel, ibid.
} 
ECHR must be considered directly applicable after accession. This will mean a change to the current legal situation under Article 6(3) TEU, which does not affect the relationship between the ECHR and national law. ${ }^{119}$ Yet, as will be shown below, accession to the ECHR will not enhance the internal protection of fundamental rights beyond the guarantees already provided by the EU Charter of Fundamental Rights.

There are no further difficulties where actions and omissions by the EU's institutions are at issue before the European Court of Justice: the ECJ must apply the Convention. However, where Member State action is concerned the answer is far less clear. The difficulty stems from the janiform character of national authorities: they act (1) as authorities of the Member States stricto sensu, ie when implementing Member State legislation drawn up in the exercise of the Member State's own sovereignty and (2) as authorities implementing EU law. The problem is, therefore, how to determine under which circumstances the ECHR is applicable as part of EU law and under which circumstances it is applicable according to the constitutional rules of the Member State. This distinction is important because within the legal orders of the Member States, the status of EU law usually differs from the status of ordinary international law such as the ECHR. The United Kingdom is a case in point. Section 2 of the European Communities Act 1972 as interpreted by the House of Lords in Factortame $^{120}$ establishes that European Union law takes primacy over domestic law. ${ }^{121}$ In cases of conflict, the UK's courts are thus under obligation to disapply domestic law in so far as it contradicts EU law. In contrast, where a piece of UK legislation is found to contradict the ECHR, the courts are under obligation to interpret that legislation in accordance with the ECHR ${ }^{122}$ and where this is not possible, they can make a declaration of incompatibility. ${ }^{123}$ In the latter case they are nonetheless bound to apply the legislation. If the ECHR were to be applied as part of EU law, however, by virtue of the Haegman doctrine it would have to be accorded the same effect as EU law and would thus take primacy over domestic legislation in case of a conflict.

Regarding the ECHR, the root of the complication lies in the membership of both the EU and its Member States to it. According to Article 216(2) TFEU, the Union's agreements are also binding on the Member States. It should be noted that Article 216(2) TFEU only has internal effect and does not alter the responsibility on the international plane. This means that internally the Member States are obliged to comply with the entirety of an agreement which was concluded by the EU alone. Where so-called mixed agreements are concerned,

\footnotetext{
119 Case C-571/10, Kamberaj [2012] ECR I-00000, para 62.

120 Factortame Ltd v Secretary of State for Transport (No 2) [1991] AC 603.

121 For a detailed discussion of P Craig, Britain in the European Union, in J Jowell and D Oliver (eds), The Changing Constitution, 6th edn (Oxford University Press: Oxford, 2007), 84, 91 et seq.

122 Section 3 Human Rights Act 1998.

123 Section 4 Human Rights Act 1998.
} 
ie agreements concluded by both the EU and its Member States, only the EU part of the agreements is binding on the Member States qua EU law. The remaining part is binding on them qua international law. Since the ECHR will be concluded by the EU alone, it will not be a typical 'mixed agreement'. Nonetheless after accession both the EU and all Member States will be parties to it so that it should be considered a mixed agreement and the question arises in how far the Member States are bound by it as part of EU law. In order to answer this question it is necessary to briefly analyse the rationale behind mixed agreements and their potential for direct effect.

Mixed agreements are usually concluded because neither the EU nor the Member States have the external competence to conclude the agreement alone. ${ }^{124}$ Only those parts of a mixed agreement for which the EU had competence are capable of having direct effect under EU law. For the other part the internal effect can only be determined by the Member State's constitutional law. ${ }^{125}$ But the situation regarding the ECHR is different. The reason why both the EU and Member States will eventually be parties to the ECHR is not that neither of them would be able to sign up to it independently. Thus the question under which circumstances the ECHR is directly applicable in the legal orders of the Member States qua EU law, cannot be answered in the same manner. It is necessary to take a different approach in order to determine its direct effect.

To reach a solution, one needs to ask what the rationale for the direct effect of EU agreements is. While the exact conditions for direct effect of international agreements and the ECJ's case-law in this respect have attracted a lot of scholarly attention, ${ }^{126}$ not much has been said about why provisions of such agreements should have such effect, if they fulfil the conditions described above. In the past, the Court largely transposed the internal approach to direct effect to international agreements. ${ }^{127}$ The main rationale given by the Court for the direct effect of the EU's Treaties in van Gend ${ }^{128}$ is the effectiveness of EU law. By pointing to the Court's jurisdiction to interpret the Treaties given to it under Article 267 TFEU, its argument assumed that the involvement of private parties in the

${ }^{124}$ M Maresceau, 'A Typology of Mixed Bilateral Agreements' in P Koutrakos (ed), Mixed Agreements Revisited (Hart: Oxford, 2010), 11, 14; for instance the WTO agreements had to be concluded as mixed agreements as (before Lisbon) the EU did not have the external competence over all aspects of services and trade mark law, cf Opinion 1/94, n 100.

$125 \mathrm{cf}$ the recent decision in Case C-240/09, Lesoochranárske zoskupenie VLKv Ministerstvo životného prostredia Slovenskej republiky [2011] ECR I-00000, para 32.

126 Just to name a few: P Eeckhout, External Relations of the European Union, 2nd edn (Oxford University Press: Oxford, 2011), 323; P Koutrakos, EU International Relations Law (Hart: Oxford, 2006), 217; F Jacobs, 'Direct Effect and Interpretation of International Agreements in the Recent Case Law of the European Court of Justice' in A Dashwood and M Maresceau (eds), Law and Practice of EU External Relations (Cambridge University Press: Cambridge 2008), 13; C Kaddous, 'Effects of International Agreements in the EU Legal Order' in M Cremona and B de Witte (eds), EU Foreign Relations Law (Hart: Oxford, 2008), 291; M Mendez, 'The Legal Effect of Community Agreements: Maximalist Treaty Enforcement and Judicial Avoidance Techniques' (2010) 21 EJIL 83.

127 Eeckhout, n 126, 381.

128 Case 26/62, van Gend en Loos [1963] ECR 1. 
enforcement of European Union law would enhance its effectiveness. Enforcement, private or public, of European Union law can only occur where European Union law is applicable. This can only be the case where the Member State has acted within the scope of EU law. There is thus a clear parallel to the responsibility of the Member States under Article 51(1) of the Charter of Fundamental Rights. ${ }^{129}$ Applied to the ECHR, this would include cases of Member State action on the basis of a provision of EU law and the compatibility of implementing legislation with the Convention.

A further question then is whether the Member States would also be responsible under the Convention for derogating from EU law. ${ }^{130}$ An answer would certainly depend on whether a fundamental right under the Convention is interfered with in such cases. A look at the classic examples from the ECJ's case-law reveals that this is hardly conceivable. For instance in Schmidberger the situation was such that Schmidberger's right to free movement of goods was restricted in order to allow a demonstration to take place. Thus none of Schmidberger's Convention rights had been at issue. In a similar vein, in Omega the claimant's freedom to provide services was affected but not its rights under the Convention. Thus derogation cases will probably be of no relevance in this respect.

The discussion has so far established that the Member States would be bound by the ECHR as part of EU law where their authorities implement obligations under EU law. The question is how this outcome can be squared with Article 6(2) TEU, which postulates that '[...] accession shall not affect the Union's competences [...]'. Coupled with Article 2 of Protocol No 8 to the Treaty of Lisbon, which provides that the accession agreement 'shall ensure that nothing therein affects the situation of the Member States in relation to the European Convention', this provision shows that accession must not lead to an increase in the competences of the Union. Conscious of these limitations contained in the Treaties, the drafters of the accession agreement provided in Article 1(2)(c) that 'nothing in this agreement shall require the European Union to perform an act or adopt a measure for which it has no competence under European Union law.' It is submitted that the result just reached does not contradict this objective. The Union's own fundamental rights already reach this far. The only true limit which Article 6(2) TEU and the Protocol might impose upon the drafters of the accession Treaty relates to the Protocols to which the Union may sign up. The draft agreement foresees that the $\mathrm{EU}$ accedes to the Convention and the first and sixth Protocol. Since all Member States are already parties to these two Protocols, accession will not substantially affect them. Furthermore, all rights guaranteed in these two Protocols are already existent in EU law today.

129 On the debate surrounding the interpretation of that provision of P Craig, The Lisbon Treaty (Oxford University Press; Oxford, 2010), 193; the informal working group on accession seemed to assume the same, cf CDDH-UE(2010)03, para 9.

130 This question is not yet settled as regards Art 51(1) Charter, cf Craig, ibid at 211 et seq. 
Yet the parallelism to Article 51(1) of the Charter of Fundamental Rights raises the question whether the potential direct effect of the ECHR has any practical relevance given that the Charter provides more extensive protection and ranks higher than the ECHR in the hierarchy of the sources of EU law. All rights contained in the Convention are equally guaranteed in the Charter. Moreover, Article 52(3) of the Charter provides that the Convention rights which correspond to the rights in the Charter should have the same meaning and scope unless EU law provides for more extensive protection. This in effect makes the ECHR the minimum standard for human rights protection in the EU.

However, there is the UK and Polish Protocol to the Lisbon Treaty, ${ }^{131}$ which by some has been hailed as an opt-out of the Charter by these two Member States. The view that the Protocol has led to the United Kingdom and Poland not being bound by the Charter seems to have been adopted by a judge in the High Court of England and Wales, who stated that ' $[\mathrm{g}] \mathrm{iven}$ the [...] Protocol, the Charter cannot be relied on as against the United Kingdom [...]'. ${ }^{132}$ The Court of Appeal made a preliminary reference in the case to the Court of Justice inter alia asking about the relevance of the UK/Polish Protocol. ${ }^{133}$ It is interesting to note that the UK government's representative before the Court of Appeal argued that the High Court Judge erred in its assessment, stating that 'the purpose of the Protocol is not to prevent the Charter from applying to the United Kingdom, but to explain its effect'. ${ }^{134}$ In her Opinion, Advocate General Trstenjak agreed with most commentators that Article 1(1) of that Protocol does not have any effect on the Court of Justice's jurisdiction to find UK law to be inconsistent with the rights contained in the Charter since the wording of that Article is limited in that it only provides that the jurisdiction of the ECJ is not extended. ${ }^{135}$ This view was also taken by the ECJ. ${ }^{136}$ In view of the ECJ's finding, the ECHR will thus not have any practically relevant internal effect in the Member States.

Thus the ECHR's status post-accession as an integral part of European Union law will have no practical consequences for the human rights protection in the Member States. Where a Member State acts within the scope of EU law, it is already bound by the Charter of Fundamental Rights, which goes further than

\footnotetext{
131 Protocol No 30 to the Treaty of Lisbon [2010] OJ C 83/313.

${ }^{132} R$ (on the application of Saeedi) $v$ Secreatary of State for the Home Department [2010] EWHC 705 (Admin), para 155 (per Cranston J).

133 Case C-411/10, NS v Secretary of State for the Home Department [2011] ECR I-00000.

${ }_{134}$ Quoted in NS v Secretary of State for the Home Department [2010] EWCA Civ 990.

135 Case C-411/10, NS v Secretary of State for the Home Department, [2011] ECR I-00000, Opinion of AG Tstenjak, 22 September 2011, para 165 et seq; P Craig, The Lisbon Treaty (Oxford University Press: Oxford, 2010), 239; C Barnard, 'The 'Opt-Out' for the United Kingdom and Poland from the Charter of Fundamental Rights: Triumph of Rhetoric over Reality?', in S Griller and J Ziller (eds), The Lisbon Treaty (Springer: Vienna, 2008), 257, at 266-8.

136 Case C-411/10, NS v Secretary of State for the Home Department [2011] ECR I-00000, para 119.
} 
the ECHR. Where the Member State acts outside the scope of EU law, the ECHR will apply to it in the same manner as today, ie in accordance with its own domestic law.

\section{Binding decisions by ECtHR?}

While the ECHR's effects as an integral part of EU law will hardly be of practical relevance, the same cannot be said for the effect of the ECtHR's decisions in cases brought against the EU. After accession the ECJ could be tempted to apply its famous dictum from Opinion 1/91:

Where, however, an international agreement provides for its own system of courts, including a court with jurisdiction to settle disputes between the Contracting Parties to the agreement, and, as a result to interpret its provisions, the decisions of that court will be binding on the Community institutions, including the Court of Justice. Those decisions will also be binding in the event that the Court of Justice is called upon to rule, by way of preliminary ruling or in a direct action, on the interpretation of the international agreement, in so far as that agreement is an integral part of the Community legal order. ${ }^{137}$

The ECHR is an international agreement with its own court, so that the dictum appears to be applicable. ${ }^{138}$ This is underscored by the rationale behind the binding effect such decisions have on the institutions of the EU. If an agreement provides that the parties to it must follow the decisions of the Court established to interpret the agreement, the EU and its institutions (including the ECJ), must be deemed to be bound by these decisions. But it is not clear from Opinion 1/91 how far that binding effect would go. It is unlikely that the ECJ envisaged a bindingness akin to a doctrine of stare decisis since such a doctrine does not exist anywhere in EU law or international law. Moreover, under international law only the decisions rendered in proceedings to which the EU was a party, are binding on it. Considering that the rationale behind the dictum in Opinion 1/91 can be found in international law, the ECJ can only be bound a decision where the EU was a party to the case. Furthermore, Article 46 ECHR shows that the decisions of the ECtHR are only binding inter partes. Therefore, under the ECHR, the ECJ can only be bound by those decisions to which the EU was a party. It is suggested that the ECJ did not intend the bindingness of such decisions to go further than is required by international law standards. It follows that where the ECtHR finds that the EU has violated the rights guaranteed in the ECHR, the ECJ will be bound by that decision when interpreting provisions of the ECHR in a subsequent case dealing with the same issue. Such a situation might, for example, arise where the applicant has

137 Opinion 1/91 [1991] ECR I-6079, para 39.

138 This seems to be doubted by A Rosas, 'The European Court of Justice in Context: Forms and Patterns of Judicial Dialogue', 2 EJIL < http://www.ejls.eu> accessed 13 December 2011. 
suffered a damage due to the EU's human rights violation and then holds the EU responsible under Article 340(2) TFEU. ${ }^{139}$ In such a case, the ECJ would be required to decide whether there has been a violation of the ECHR. Where the applicant has already obtained a decision in her favour, the ECJ would be bound to follow that judgment.

\section{Conclusions}

This contribution has tried to show that EU accession to the ECHR raises complex questions. The drafters of the accession agreement largely managed to live up to their original ambition which was to preserve the ECHR system and only make the adaptations which are necessary. ${ }^{140}$ Yet this ambition has led to an unsatisfactory solution as regards the co-respondent mechanism. While the voluntariness of the mechanism may be a matter for debate, the treatment of omissions is unresolved and contains the potential for conflict. Procedurally, the co-respondent mechanism and the prior involvement of the ECJ annexed to it will prolong proceedings and make them more complex. In contrast, the practical effects of accession are only limited in view of an already strong catalogue of human rights existent at EU level and of the responsibility of the Member States in the ECtHR for most EU action. The main improvement is therefore to be seen in the ECtHR's new jurisdiction over cases such as Connolly. A further improvement, which should perhaps not be underestimated, is the growing awareness within the EU's institutions that an external review will be possible. Recent changes to the EU's internal human rights monitoring such as the provision for a human rights watchdog for the EU's border agency FRONTEX can be seen in this light. ${ }^{141}$

But whether the accession agreement as it currently stands will be the (happy) end to a story of epic proportions remains to be seen. It is likely that further chapters to the accession saga will be added. The EU is currently in the process of adopting the internal rules governing its membership of the ECHR, in particular the rules relating to the prior involvement of the ECJ. Once these have been agreed, it is likely that the ECJ will be asked for an Opinion under Article 218(11) TFEU on whether the agreement and the internal rules are compatible with the exigencies of the EU Treaties. Even if the ECJ gives the agreement a green light, it is likely that the agreement will come under two further types of

139 Regarding the decisions of the WTO Dispute Settlement Body the ECJ has been unwilling recognize them as binding, mainly due to the peculiarities of WTO law: Case C-377/02, Van Parys v BIRB [2005] ECR I-1465; Confirmed in Case 351/04, Ikea Wholesale Ltd v Commissioner of Customs \& Excise [2007] ECR I-7723.

140 CDDH-UE 2010(01) para 5.

141 vcf European Parliament, Press Release of 13 December $2011<$ http://www.europarl.europa.eu/ en/pressroom/content/20110913IPR26455/html/FRONTEX-new-human-rights-watchdog-newpowers> accessed 13 December 2011. 
pressure: first, as the recent discussions in the Council of Ministers, to which this paper has referred, have shown, the parties concerned may not be happy with the content of the agreement and demand amendments. This may cause further delay in achieving accession. Second, there may be reasons extraneous to the actual agreement which might lead parties to the Convention to block accession. In this context one should remember the difficult birth of Protocol 14 which for a long time was blocked by Russia for political reasons.

It would therefore be overly optimistic to regard the draft agreement as the final word of the epic of the EU's accession to the ECHR. But it marks the beginning not only of its final chapter but also beckons an entirely new story on the EU's membership of the ECHR. 
Reproduced with permission of the copyright owner. Further reproduction prohibited without permission. 